\title{
建築空間における空間秩序的太陽光効果とそれらの要因 \\ EFFECTS OF THE SUNLIGHT ON SPATIAL ORDERS AND THEIR CAUSES IN ARCHITECTURAL SPACES
}

\author{
小泉 隆*, 鈴木信 宏** \\ Takashi KOIZUMI and Nobuhiro SUZUKI
}

\begin{abstract}
We obtained 9 effects of the sunlight on spatial orders caused by light composition in a space: Expanding the Horizontal Plane, Giving Depth, Dimming Direction and Distance, Marking Outlines of the Form, Generating Unity, Generating Direction, Emphasizing the Integration of the Spaces, Connecting the Spaces, Emphasizing the Articulation of the Spaces.

We also obtained factors causing these effects by examining the location of the light in the space, the form of light in the space, the character of the outstanding light.
\end{abstract}

keywords: effects of the sunlight on spatial orders, factors causing the effects of sunlight, light composition in a space,
characters of the outstanding light, easy perception of light and space
空間秋序的太陽光効果, 光效果の 要因、空間に对する光の構成, 際立ち光㮔類, 光と空間の知覚のしやすさ

1. 序

建築空間における太陽光の採光方式は通常、頂光、側光なよ゙といっ た位置による分類が多いが、空間中央に点的にある光が空間にまとま りを与えたり、隣接空間の境界部分に線的にある光が空間の分節を強 調する之いったように、建築空間に取り込まれ空間内で際立って捉え られる太陽光の、空間に対する構成の仕方を主要因とし、空間秩序的 な光効果を与える太陽光効果とその要因の構造夕イプがありそうであ る。ここで空間秩序的光效果とは、物によって既にある空間秩序を光 か強調したり、新たに光が空間秩序を作り出す場合の効果を指す。前 稿 : 小泉隆、桶師德行、鈴木信宏「まとまり之方向性を与元る自然光 タイプ」 2:では、そのような空間秩序的光効果の中で、単一空間にお いて特に基礎的之考えたまとまりと方向性を取り上げ、それらの要因 となる光の構成夕イプとして、中心光、包囲光、充満光、軸線光、軸 上目標光の 5 つを得た。しかしながら、床一面に面的に広がる光が空 間に広がりを与えるといった，単一の空間におけるるの他の空間秩序 的な光効果、また隣接する 2 つ空間をまたぎ貫く線的な光がそれら 2 空間を連結するといった、複数空間に対する空間秩序的な光効果す 色々ありそうである。

\section{2. 研究の目的およひ視点}

本研究は、設定視点に基づく多数実例の観察を主たる方法に次の目的を 設定し、太陽光設計のデザインガイドラインに役立てよう之試みた： 1)建築空間に取り込まれ空間内で際立って捉元られる太陽光(以下门際 立ち光」) の、空間に対する構成の仕方が主要因となって与える、a) 空 間秩序的な光効果にはどのようなものがあるかを、とまりと方向性も 含め幅広く探し整理する事。そして建築設計における基本設計段階等 で用いやすいレベルて、2jそ机光效果の要因を、b.1) 光の位置、b.2） 光の形驡、c) 際立ち光種類の 3 つの操作項目下の具体内容に求め整理 する事。3）そしてそれら具体内容の組み合せによって空間秩序的光 効果とその要因の対応関係を定性的に体系化する事. そして4) 要因 の差に着目して、空間秩序的太陽光効果とその要因の構造夕イプを得る 事を目的とした。すなわち，空間に対する光の構成を、空間中央にあ る、隣接空間の境界部分にあるといった、際立ち光の空間全体に対する 位置と、点的、線的、面的、塊的の 4 つに代表させた、空間全体に対す る光の形態の組合せによって捉えることにした。また反映した際立ち 光による空間への梁み与えといった、際立ち光の種類も要因になる光効 果については、その際立ち光の種類も捉えることにした。

尚、まとまりと方向性に関しては、前稿aてで詳細に解説をしたので、 今回幅広い効果を総して体系的に再整理した要因の具体内容及びその組 み合わせの結果を結果表中にのみ記し、解説は省略する。

\footnotetext{
* 東京理科大学工学部建築学科 助手. 工修
}

** 東京理科大学工学部建築学科 教授. 工博 Research Assistant, Dept. of Architecture, Faculty of Eng., Science Univ. of Tokyo,
M. Eng. Prof., Dept. of Architecture, Faculty of Eng., Science Univ. of Tokyo, Dr. Eng. 


\section{3. 研究の位置付け}

1)空間に対する光の構成を主要因とする心理効果を扱った既往研究て は、空間内での輝度や照度の分布、照明器具の種類とその構成などと、 落ち着き、安定感、活動性、变化性といった空間の雾囲気全般b) 〜d) 輝き感》、明るさ感〉なざとの相関を扱った研究、又それらと好まし い行為などとの関係を扱ったものるが多いが、空間秩序的光効果を取 り上げた研究は少ない。又上記研究はそのほ之んざか環境工学、環境 心理学の分野において行われている研究であり、評価実験などにより 捉えた心理量とミの要因となる輝度や照度といった物理量との因果関 係を深く詳紐に定量的に探るものが多い。それらに対し本研究では研 究者による設定視点に基づく多数の建築実例の観察より、それら実例 に潜む魅力的な空間設計に向けて重要と思われる空間秩序的光効果を 探し整理し、それらの要因を、建築設計における基本計画段階などに おいて直接的に応用しやすいように，視点に示したレベルで一般化に 向けて抽象整理し、定性的に体系化しようとする点が異なる。

2) 空間秩序的光効果を扱った研究は建築計画分野においていくつか ある。既報: 鈴木信宏・明田川洋「德利屋の空間構造と光」(1991) ${ }^{\mathrm{h}}$ ) と「ウィーン郵便貯金局の空間構造と光」(1993) i)では、個別の実例 においてみられる数個の空間秩序的光効果を扱った。その他には、特 定の建築家の作品において方向性に限った松本・八木他の「アアルト の作品の方向性」(1997) ${ }^{j}$ ，雾囲気全般の中でその一因子として空間 秩序的光効果を扱った高野・船越他の「移動空間における光効果 (1988) k)なよ゙がある。しかしながら本研究のように多様な幅広い実例 を対象に幅広い空間秩序的光効果を取り上げ、それらの要因の体系化 を試みている研究は見当たらない。

\section{4. 研究方法と手順 (表1にその概要を記す)}

\section{1 対象実例 120 例の遭定}

1) 研究者らによる的 2000 例の際立ち光をもつ建築作品実例の観察よ り (写真之図面、重要実例には加えて実地調查)、際立ち光の空間に対 する構成が要因となって、空間秩序的光効果を与えていると判断した 実例在予備選定した: 的 300 例。母体資料としたそれら䄪2000実例 は、透過光や反射光またその色などの光自体の特徵が多样であり、点 的、面的、点連続による線的な光といった光の形態及びその具体形状。 上部、側部、覆う、囲う、空間の中心にあるといった光の位置。単数、 複数といった光の数による、空間に対する光の構成のされ方が多様な ものである。また空間のスケールも 3 畳間の茶室から体育館・スポー一 ツホールのような大スケールまで。空間形態は、球状のものから細長 いもの等に散らばる実例である”。

2）予備選定した 300 数実例を、研究者らが相対的に比僌観察しながら (写真之図面、重要実例には加えて実地調查（約100例)）、魅力的な空 間設計に向けて重要で一般的之判断した空間秩序的光效果を鮮明に与 えていて、且つその効果の要因がb.1) 光の位置、b.2) 光の形㿟心 c) 際 立ち光種類の組み合せにある之判断した実例120例を対象実例とした。

\section{2 锶察による各対象実例の奻果内容と要因の予想及びそれ} ら効果と要因に対する第三者や作者の記述による重みつけ

研究者に上る対象実例の写真・図面、(重要実例については現場)。の 観察より、各対象実例の効果内容とその要因となる光の位置、光の形 態、際立与光種類を予想した。また対象実例に対する第3者や作者の 記述を雑誌や作品集などより調へ、そこでの効果またはその効果の要 因老支持する記述古確認し、一部の実例において重みづけた。

\section{3 対象実例における予想内容の相対比交による考察}

全対象実例の写真や図面および予想した効果之要因の、相対的な比

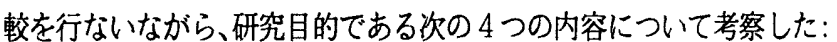
1）空間秩序的光効果の効果内容の分類整理、2）操作項目下の要因具 体内容の分類整理、3）操作項目下の要因具体内容の組合せによる、各 光効果と要因の体系的整理、4) 効果と要因の構造夕イプの整理。

\section{4 代表実形と既往理侖の吟味による重みつけを行ないなが らの再考察及びその考察結果の整理}

そしてさらに、後述する1）代表実例の吟味と2）既往理論の吟味に より、4つの目的に対する考察内容を重みづけながら再度考察を行な うという作業を数度に渡って繰り返し、それら内容の一般性拉よび論 理性か確認できたところで、3）その考察結果を整理した。

1) 代表実的の吟味: 察立ち光・光の位置・光の形的の要因具体 内容及ひ空間内での光と空間の知党のしやすさの吟味

対象実例中から、効果を支持する記述があること、又洨効果之要因 の因果関係が中でも明膫なことを条件にし、実例の多い要因構造夕イ プについては要因か類似のものを適宜省きながら、代表実例を要因構 造夕イプ毎に複数例選出した : 計 52 例。

そして操作項目下に分類整理した要因具体内容各々について次の指 標を設认、代表実例において园面や写真よりそれら指標の数值等を算 出しながら要因の具体内容を吟味した：b.1) 光の位置については、水 平断面における光の長さ／空間の全周長、なよ゙。 b.2) 光の形態につい ては、光の面皘/床面積、なよ゙。c）際立ち光種類については、際立っ て捉えられる事を可能にしている、透過や反射させる具体的な素材種 類。志江反映した光についで、反映している像は何であるか、なよ゙。 尚、際立ち光かざうかの判断は、写真や現場での観察より、周囲との 輝度対比やその絶対量の高さ、そして物ではなく光独特の特徽的な見 え方であるかに注意しながら、一般的に光として際立って捉えられる 之判断して差し支えないと研究者らが判断したものを特定している2。 また、実際の空間においては、それら際立ち光の空間に対する光の構 成が知覚しやすい状態にないと効果が生じないという視点から、空間 内での主要と判断した視点場とその視線方向うにおいて、60度のコ一 ンと想定した見易い視野4)に対する光之空間の在り方や、光や空間に 対する視角度などを图面等から提えた。こしてそれらを踏まえ元視点場

\section{表 $1:$ 研究方法と手順の概要}

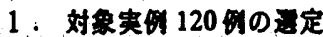

1) 光の形態、位置、質や色、空間の大きさなどに散らばる的 2000 実例

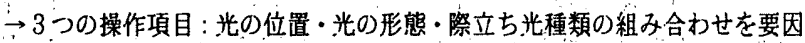

として，空間秩序的光効果を与えていると判断した対象実例 120 例

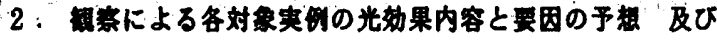
それら効果と要因に対する第三者や作者の眍述による重みつけ

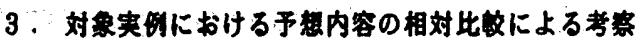

考察内容 (4 つの)研究目的):

1）空間秩序的光効果の整理

2） 3 操作項目下の要因具体内容の整理 (光の位置・光の形態・際立与光種類)

3）要因具体内容の組み合わせに上る勃果と要因の体系的整理

4）効果と要因の差による、勃果と要因の構造夕イプの整理

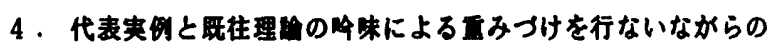
再考察及びその考䩘結果の整理

1) 代表実例における光の位置・光の形態・際立ち光種類の要因具体内容 及び空間内での光と空間の知覚のしやすさの吟味

2）効果之要因の因果関係を支持する既往理論の吟味

考察内容の一般性、論理性の確認 $\rightarrow$ 考察結果の整理 
之視線が移動した場合なども考慮しながら、それら効果創出の前提条 件亡なる笁間内での光之空間の知覚のしやすさを吟味し、確認した。表 2 中段 I. 1 とI . 2 欄に考察の結果得た要因具体内容及び知覚のしや すさに対し判断基準として設けた指標を記す。

\section{2 ）奻果之要因の因果関係を支持する既往理論の吟味}

予想した各効果とその要因の因果関係に対し、それらを支持する既 往理論を吟味し、重みづけを行った。既往理論什空間秩序や形態構成 及びそ机ら効果に着目し建築空間や都市空間を論した研究や文献、そ して知覚心理学における図と地の概念や色の現われ方といった知覚の 基礎理論に関する文献存中心に用いた 5 。

\section{3）考察結果の整理}

上記による重みづけをしながら考察を繰り返し、それら内容の一般 性うよび論理性が確認できたところで、考察結果を整理した。

\section{5. 研究結果}

ここでは代表実例の吟味等の考察を行った上で得た結果のまとめを 先に述心、次に 6 にて結果解説をする。

\section{1 a) $9 つ$ 空間秩序的太淂光奻果}

魅力的な空間作りに重要で一般的と判断した空間秩序的太陽光効果 として、まとまりと方向性も含め単一空間に対する光効果 6 つ、複数 空間に対する光効果 3 つの計 9 つの光効果学得它（表 2 の 1 縦軸）：

ア）単一空間：1）水平基盤面の広がり与元、2）鈆直下方への梁み与 元、3）方向性・距就感の弱め、4）形態の際立たせ、5）ま之まり与え、 6) 方向性与元。

1）複数空間：7）統合の強調、8）連結、9）分節の強調。

5.2 光奻果の要因となる b.1）光の位置、b.2）光の形的、c） 際立与光種類の分類整理（表 2 横軸の 3 )

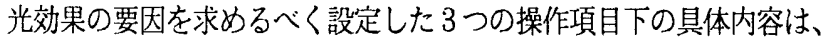
次の項目に分類整理出来た。

\section{b）空間に対する光の構成：}

b.1）光の位置は、単一空間に対して、前稿のまとまりの要因となる 3）中央近傍、5）連続包囲、6）空中充満之、方向性の要因となる44) 軸 上の 4 項目に新たに、形態際立ての要因となる1）主要な角と2）主要 な稜線、広がりの要因となる7）床一面。方向性・距離感の弱めの要因 となる8）全空間限定面、以上 4 項目を加えた計 8 項目に整理出来た。 複数空間に対する光の位置は、統合の要因之なる1）中心空間にある 之2）小空間を包含する、連結の要因之なる3）隣接空間を貫く、分節 の強調の要因になる 4) 隣接空間の境界部分にあると5）別空間に隣接 する、の小計 5 項目。以上合計 13 項目の光の位置に整理出来た。そ して軸が水平なのか鉛直なのか、包囲が覆いなのか井いなのかといっ た水平方向と鉛直方向の違いに着目してさらに細分した：

乃）単一空間に対する光の位置・8項目:1) 主要な角、2) 主要な稜 線、3）中央近傍、4）軸上（鉛直方向之水平方向）、5）連続包囲（覆 (之囲(）、6）空中充満、7）床一面、8）全空間限定面。

1）複数空間に対する光の位置・5項目 :1）中心空間にある、2）小 空間を包含する（覆いと囲い）、3）隣接空間を貫く（鉛直方向之水平方 向）、4）隣接空間の境界部分にある（鉛直方向之水平方向）、5）別空間 に隣接する（鉛道方向上水平方向）

b.2）光の形愳は、1）点的、2）線的、3）面的、4）塊的の 4 項目。 c）際立与光種類は、反映際立与光による深み与元、等質際立ち光に よる方向性・距離感の弱めといった、際立ち光種類の具体内容力効果 作り出しの条件となる、2）反映際立ち光、3）等質際立ち光之、その
具体内容が作り出し条件にならない1)際立ち光、の3 項目に整理した。 尚、光之空間の知賞のしさすさの吟味に際しては、主要な視点場之 その視線方向における見やすい視野60度における光と空間の知覚状態 を、光については1）視野に光が納まること、2）視野を越えるが、視 野内で光の大部分が納まること、3）視野を光が満たすこと、の3つ。 空間は、4）視野内で空間の大部分が納まること、5）視野を空間が満 たすこと、6）複数空間が同時に知覚できること、の計 6 項目に着目し て整理した上で，それらを踏まえ、視点移動の場合も考慮し、光と空 間の知覚のしやすさを確認できた（表 2 横軸の 4 )。

\section{3 空間秩序光効果之要因の体系化および 15 の要因梅造 $917^{\circ}$}

9 つの光効果の要因を 3 つの操作項目下の具体内容の組合せによっ て体系的に整理した。 そしてその要因の差に着目して、9つの光効 果に対し、その要因の構造夕イプ15個を得た（表 2 の 2 綐軸）。

\section{6. 研究結果の解説 : 空間秩序的太謁光効果とその要因の構造 タイプおよひ代表実例}

ここでは要因の構造タイプごとに、代表実例分析の主な結果を示し ながら、各効果とその要因について解説する。表 2 の縦軸に代表実 例52例を記し、表中にその判断基準とした吟味結果を記す。また表 2 の6 稼軸に効果を支持する記述の有無を記す。

\section{つ）単一空間に対する光奻果とその要因櫵造夕イプ}

1）水平基盤面の広加り与元/床一面・面的・反映祭立ち光

II T 体育館（写真 1) では、空間全体が暗い中、光沢のある夕イ ル床の一面に、空間の全周囲を囲む乳白ガラスを透過した白い光とそ の逆光を受けた人のシルエットを反映していた。そしてその面的な形 態をもって際立って捉えられる光が、水平基盤面の広がりを学艺てい た（光面皘／床面皘：100\%)。空間の端から知覚状態を検討する之、前 面の光床面の角までは水平視角度60度であり、見やすい視野内で瞬時 に光の全体か知賞しやすい状態にあった6う。た、S.C.UP STUDIOで

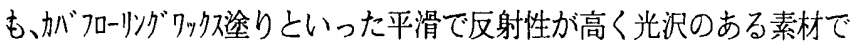
あることが、前面の開口部を反映する際立つ光を作り出していた。そ してその光も床一面に面的に広がっており、水平基盤面の広がりを強 調していた(光面積，床面積：65\%、光の幅に対する水平視角度：65度)。

水空間の研究でも、面的な水面が空間に広がり感を与えることが確 認できている7)。尚、そこでは水面の幅に対する水平視角度が見易い 視野に讵、54度を超宎るように見える時に、また対岸への視線入射角 度が 2 度以下にあるときに、その広がりの効果は影著に現わ扎る事が 確認されているが、この床一面に満ちた面的光については、本研究の 視点を越えるが、効果創出の前提条件である知覚のしやすさだけでな く、その知覚条件自体も効果の条件や効果の強弱に関わりそうである。 以上の分析よりこのタイプは、床一面に満ちた面的に反映する際立 ち光か、、水平基盤面である床面を視覚的に強調し、その水平基盤面の 広がりを与える光効果と整理した。

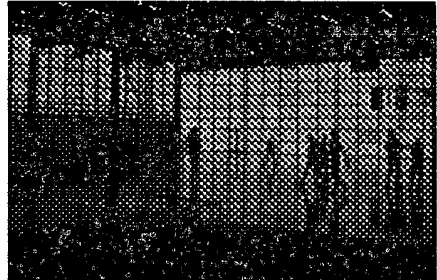

写真 1：II T体育管

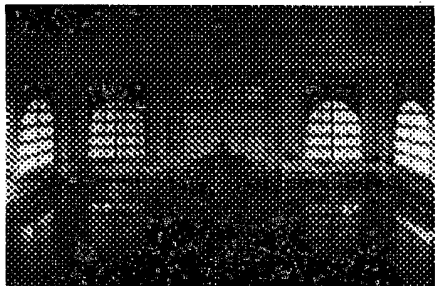

写真 2 : 鹿苑寺金閶 
表 2 : 空間秝序的太陽光効果とそれらの要因およひ代表実例

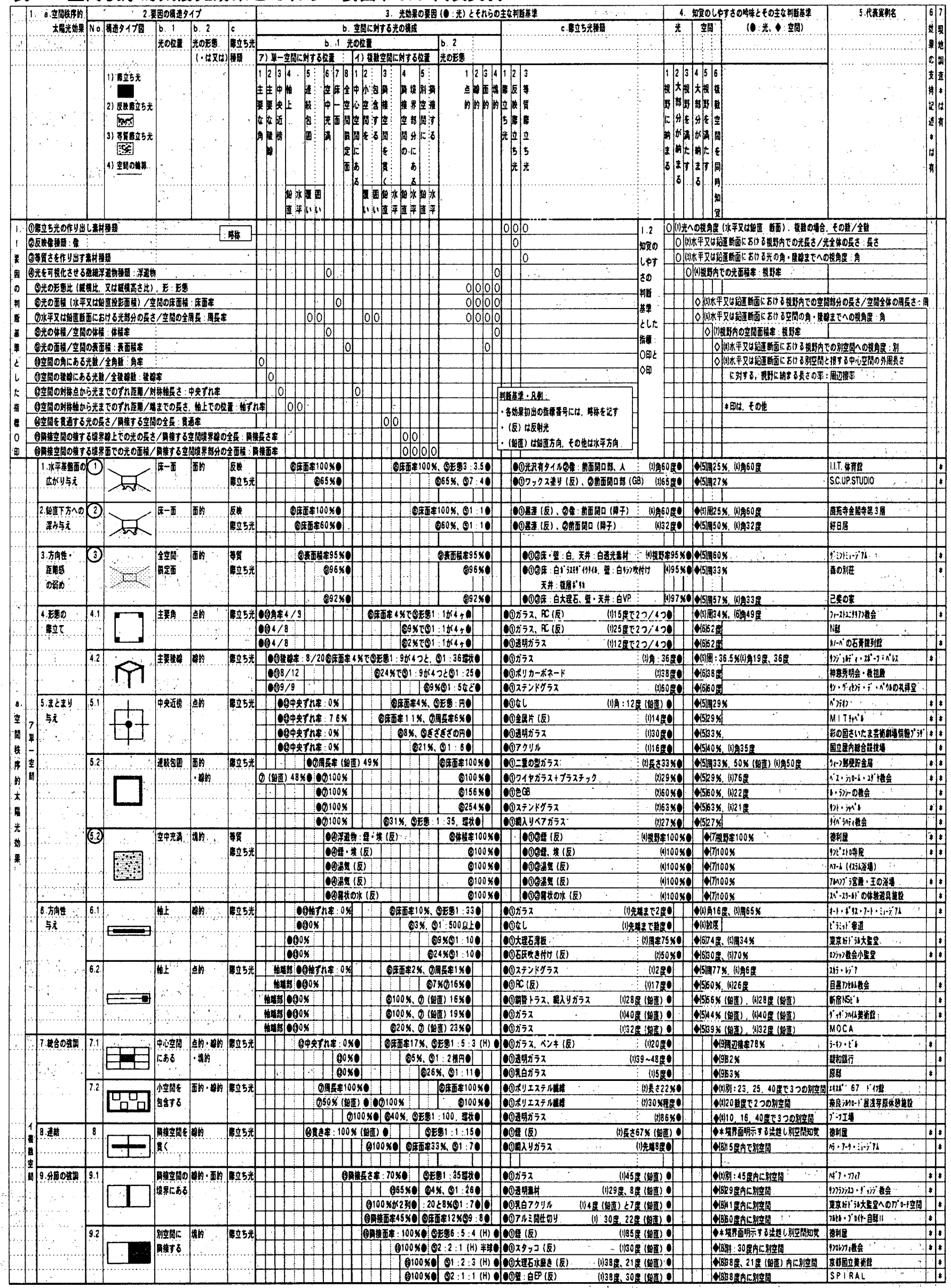

仓：構造タイプ:No.にO印：物にはない光に特徴的な効果要因の構造タイプ 


\section{2）鉛直下方への深み与元/床一面・面的・反映淂立ち光}

鹿苑寺金閣の第 3 層究境項部（写真 2 ）では、四方の障子から入 射した光が、壁・天井の金箔に照り返し、それらの像が黒漟叙の床一 面に面的に反映し、鉛直下方への深みを与えていた（光面積／床面積： 100\%、光の形態比（縦横比）1:1）。入り口から正面壁の両端までの視 角度は60度で、見易い視野内で光之空間の大部分が納まり、それら全 体が一望に把握しやすい状態にある。また好日居でも黑漆塗りの床が、 前面の開口部の像を写しだしながら床一面に面的に反映し，空間に深 みを与えていた（光面積／床面積：60\%)。

床面が通常の表面色 ${ }^{8)}$ として見える場合は、固いしっかりとした水 平床面として見えるのに対し、床面がそのような反映光に満たされ、鏡 映色 ${ }^{8)}$ として現われることによって、その面の向こうへとその像があ るように見えるため、鉛直下方への深みを感じさせると思われる。水 空間の研究でも、水に映る反映像が空間に鉛直下方への梁みを与える 事が確認できているき。

以上の分析よりこのタイプは、床一面に像をともなって反映した面 的な際立ち光が、その面の法線方向へと続くように感じさせ，空間に 鉊直下方への梁みを与える光効果と整理した。

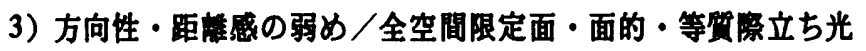

ゲミントミュージアム (写真 3) では、トップライト及び乳白色の 㹡散性のある天井面により二重に搪散した白い光が空間内に入射し、 幅木なごの笑起物がく平滑な白い壁そして床にその光が再度搪散反 射している。その為、周囲の白い光面の中て唯一黒く対比的に弁別し て捉えられる前面の開口部分を除く、空間限定面のほとんど全てが白 い等質な際立った光として提元られ、空間の方向性・距離感を弱めて いた。等質な光を作り出している白い素材部分の空間全表面皘に対す る面積率を測ったところ、その表面積率は約95\%であった，また主要 視点場からの見易い視野に近い35 mmカメラでの撮影部分において、等 質な光が占める割合（視野内率）を測ったところその面皘率も䄪 $95 \%$ であった。その他の例でも、同質さを作り出す仕上げ素材を吟味し、 また主要な視点場からの視野内での等質に捉えられる部分の面皘率を (視野内率)をはかったところ、森の别在では、等質と捉えられた光を 作り出す素材は、床: 白いガラスモザイクタイル、壁: 白リシン吹付 ケ、トップライトは複層ポリカーボネードであり，その視野内率は 95 $\%$ 。甲斐の家では、床: 白大理石、壁・天井 : 白ビニルペンキであり, その視野内率は $97 \%$ であった。

通常人間は建築空間内で、はっきりと知覚出来る水平な床面や鉛直 な壁などを基準に空間定位すると言われているが10)、床面や壁などの 空間の限定面すへてが等質な光として現わ扎、全ての面に対してはっ きりした定位がしにくい場合に、方向性・距䧺感の消失した空間のよ うに感じる場合がある。知覚心理学において、視野をアクリルのピン ポン玉のようなもので覆った時のように一種類の光だけで視野が満た されている一様な視野は等質視野と呼ばれている。そして被験者に対 しその等質視野の状態を作り出したときの㬰験結果によると、そこで

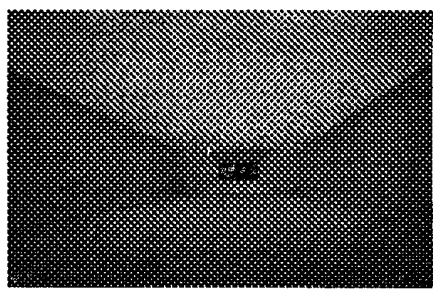

写真 $3:$ ゲミントミュージム

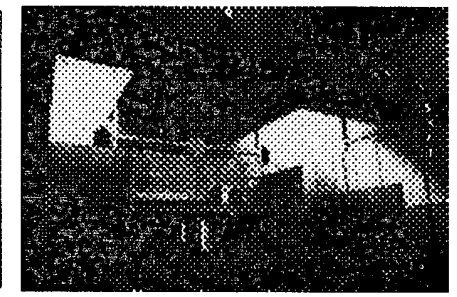

写真 4：ユニタリアン数会
の特徴として、視野は不確定で確定した距離感が存在しないこと、非 構造的であること、澧い霧状に包まれたかのような不確定な状態が知 覚されるなどが報告されている111。また深い霧などの中に入った時に、 ほぼ等質視野の状態が起こるといわれ、そこでは物体の表面は定かで なく遠近感も暧昧で、形、大きさ、方向等の知覚が成立しにくいとい われている12)。

以上の分析よりこのタイプは、等質視野に近い状態が建築内部空間 に展開した例であり、空間限定面の全てが面的で等質な際立った光に なることによって、空間への定位を不確定にし、空間の方向性・距離 感を弱姯効果と整理した。

\section{4）形態の際立て}

\section{1）形賏の祭立て／主要な角・点的・際立ち光}

ファースト・ユニタリアン教会（写真4、図1）では、約 $21 \mathrm{~m} \times$ $19 \mathrm{~m}$ の矩型の平面形に対し、 $4.3 \mathrm{~m} \times 3.3 \mathrm{~m}$ のトップライトがその四隅に あり、そこからの光涺壁面に反射し点的に際立って捉元られ（光面皘 率3.7\% × 4 つ=約 $15 \%$ )，空間の角を強調し、空間形態を際立ててい $た^{13)}$ 。知覚状態を検討してみると、入り口部分からその正面壁の両端 までへの視角度は 49 度であり、その両側に手前へと囲む壁が見易い 視野60度内に納まり、空間の大部分を一望に知覚しやすい状態にある。 そしてその 60 度視野内で、角にある二つの点的な光がそれぞれ視角度 15 度で同時に知覚出来る。自由に動き回れるこの教会内では、その他 の 2 つの光も空間の全体と共に容易に知覚できる状態にある。またそ の他の 2 例も、ほぼ同じ立方体の空間でその上部四隅に点的な光があ るタイプである:N (光面皘率/床面積 $9 \%$ 代 4 つ)，カノーバの

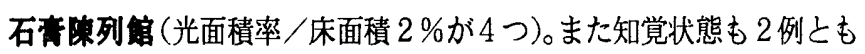
同様に, 見易い視野 60 度内で、一つの光に対し視角度 12 度 (カノーバ の石塾陳列館）と25度（N邸）で、二つが同時に納まる。

空間のボリュームは、頂点、䂭線、表面によって成り立っているが、 それらを光によって視覚的に際立たせることによって、その空間の輪

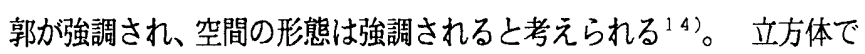
ある 3 つの代表例では、光の角にある率は、空間の全角の 8 つに対し、 4 つの半分ではあるが (角率)、空間の.上部にあり、またその知覚がし やすいために、空間の全体形態が強調されやすいと考えられる。

以上の分析よりこのタイプは、空間の主要な角に位置する点的な際 立ち光が、空間形態の輪郭を視覚的に強調し、空間形態を際立てる光 効果之整理した。

\section{2）形稳の祭立て／主要な稡線・線的・際立ち光}

サン・ショルティ・スポーツパレス（写真 5 ）は、約 285m X約 $230 \mathrm{~m}$ の空間全体に対し、その屋根部材相互の接合部分であり空間形態 の主要な棱線にあたる部分に、幅約 $8 \sim 17 \mathrm{~m}$ の細く線的な際立った光 があり (光面積率: 13\%)、その光によって空間の棱線か視覚的に強調 され、空間の形態を際立てていた ${ }^{15}$ )。空間の全稜線数に対する光によ る稜線数は、 $8 / 20$ である。人り口付近加視角度を検討して見ると、 空間の稜線の角部分までは、上部の角 : 視角度 19 度、下部の角 : 36 度

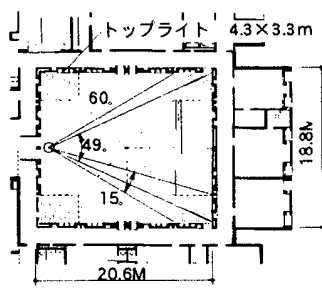

图 1:ユニタリアン数会

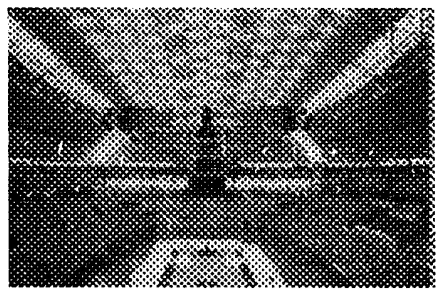

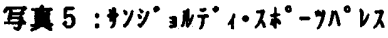


で見易い視野内に納まり、空間の大部分が一望に知賞しやすい状態に ある。そしてその視野内で複数の線的な光が同時に知覚出来る。また その他 2 例も空間の稜線部分がスリット状のトップライトになってい る例である。空間の全棱線数に対する光による稜線数は、神愬乔明会：

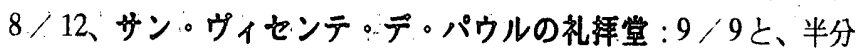
以上であり、床部分を除けばそのほとんよ゙が光として際立っている。そ， して両例共にそれら光と空間は知覚しやすい状態にあった。

角光之同じく、稜線の強調によって空間の輪郭が強調され空間の形 龍は強調される亡考えられる14)。

以上の分析よりこのタイプを、空間の主要な稜線に位置する線的な 際立ち光か、、空間形態の輪郭を視覚的に強調し、空間形態を際立てる 光効果亡整理した。

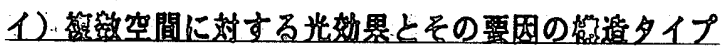 7) 统合の弦調}

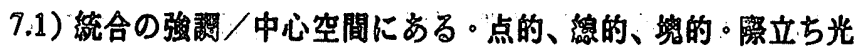

ラーキン商会ビル（写真 $11 、$ 図 2) は、4 層の吹き抜け部分の執務 スペースを中心に、その周囲に4層分の執務スペースか配置されてい る。そしてその中心空間は全面のトップライトからの光によって満た され光の3、次元的な領域として、周囲の空間から塊的な光として際 立うて捉えられる（光形態比 $1: 5: 3(\mathrm{H})$ )。その為周囲の空間からそ の中心空間への集中性は高められ、中心空間による統合が強調されて (いる）。知覚状態を検討してみると、塊的な光の満ちたボールを中心 に、その見易い視野60度内で周囲の空間のほとんよ゙が同時に知覚出来 る。平面図において周囲の空間に接する中心空間の水平周長に対し、60 度視野内に納まる範囲を測うたところ $78 \%$ (周辺接率) であり、ほと んよ゙の周囲の空間が同時に知覚できる。ままた同様に中心空間にある光 への集中に上る統合であるが、その中心空間が細長く軸性をもって両 側に小部屋を配しその中心空間に線的な光 (光面皘人床面皘: $26 \%$, 光 形態比 $1: 11$ ) があるタイプで、またその断面形からは次節で取り上げ る小空間を包含するタイプにも位置付けられる原姆 (写真12) があっ た 7?:ここでは中心空間にある線的な光が，視野内でその先端に対し 視角度 5 度で納まり、同時にその周囲の小部屋のほとんどが知覚でき る。平面図に扎いて周囲の空間に接する中心空間の水平周長に対し、60 度視野内に納まる範囲を測ったところ、63\%であった。

複数空間の形態構成のパターンの一つに中心性によるものがあるこ と。そしてそこではその中心空間が周囲のその他の空間を集中性に よって組織化するこよはよく言及されている13)。

以上の分析よりこのタイプは、形態構成的に周囲に複数の空間を配 し、周囲の空間と視覚的に相互につながっている中心空間において、そ の中心空間にある点的・線的或は塊的な際立ち光が、周囲の空間から

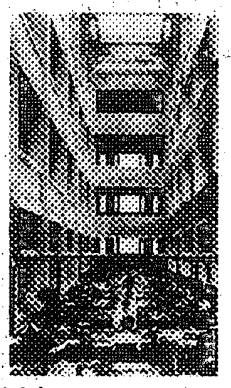

写傎 $11:$ ラーキン 商会商会ビル

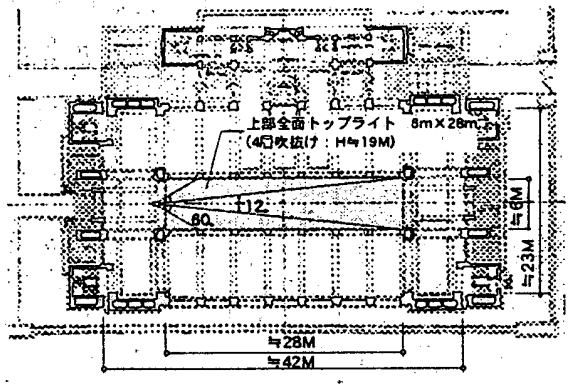

图 2:ラーキン商会商会ビル 平面图

中心空間・集中性を強調し、複数空間の統合を強調する光勃果と整 理した。

7.2）统合の强調／小望間を包含する・面的、缐的・磨立ち光 エキスポ・ 67 ドイツ館 (写真 13) では、ポリエステル䋞維の膜で 覆われた展示会場内に、床の持ち上げなどによって形成されたいくつ もの小空間か配置されている（水平断面における全周長に対する小空

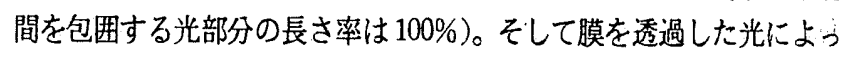
て際立って捉えられる面的でそれら小空間を包含する光が，小空間の 統合を強調していた。ある主要と思われる視点場とその視線方向から 知覚状態を検討してみると視野 60 度内で、23、25、40度の視角度で持 ち上げられた3つの小空間を空間を包含する光とともに同時に知覚で きる状態にあった，また面的な光でなく線的な光の例であるブーツエ 幆では、透明ガラスのハイサイドライトにようて際立って捉えられる 線的な光か、、複数の空間を環状に取り囲み、それら空間の統合を強調

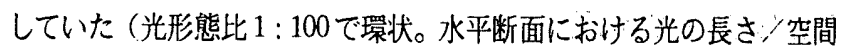
の全周長 : $100 \%) 。$

複数の要素在囲认込ん代り包囲することが、内部の要素を組織化す ることも一般的に良〈言及されていることである19?。

以上よりこの夕イプは，小空間を包含する面的或は線的な際立ち光 か、視知覚的に空間の包含関係を強調し、小空間の統合を強調する光 効果と整理した。

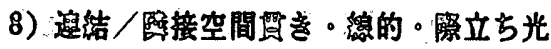

ハラ・アーク・ミュージアム（写真 14、図 3)では、連続する幅 約 $11 \mathrm{~m}$ の 2 つの゙ャラリーを貫く幅約 $4 \mathrm{M}$ 、長さ約 $27 \mathrm{M}$ のップライ 卜の線的な光が、その膦接する2空間を連結していた（光面皘，床面 積 : 33\%。光形態比 : 1:7)。その光は隣接する空間の水平方向全長に 対し、ほぼ 100\%（貫き率) で貫いている，知覚状態を倹討すると、手 前のギャラリーから見易い視野 60 度内で手前の空間を、そして視角度 15 度内で向こうの空間が同時に知覚できる。またトップライト先端へ の視角度は 8 度で視野内に光が納まり、二空間之光が同時に知覚しや すい状態にある。また鈆直方向の例の嗦利屋（図 4) では、晴天時、 煙によって可視化された光の束が、トップライトから床面にまで落ち、 明るい上部の朴組ふの空間と下部の暗いいるりの空間を貫き（貫き率 100\%)、上下空間を連結しているという光の効果が、現場アンケートに よ゙って捉えられている20)。こでは、上部と下部の分節を明示する梁

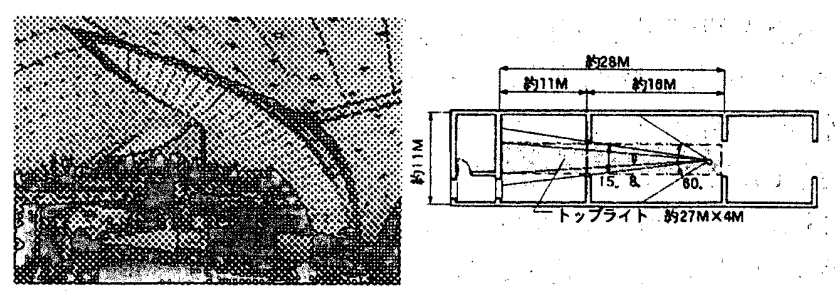

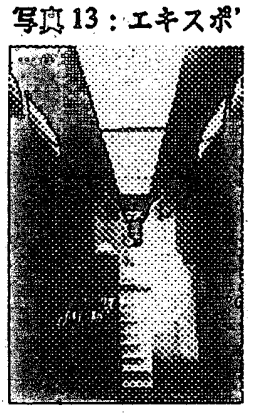

军项 12 : 原鄂

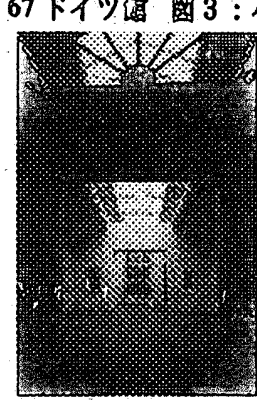

写缼 $14:$ : ハラ・アー ク・ミュージアム

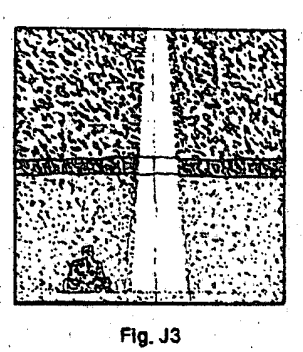

图 4 : 德利屋阙天時 被馀者のスケッチ 
組みを通して上部の空間を見上げることによって、下部の空間と上部 の空間が同時に知覚しやすい状態にある. また見上げたその 60 度視野 内で、光の束の長さの 67\%が納まり、知覚しやすい状態にある。 連結も複数空間を組織化する手法としてよく言求されている21)。 以上よりこのタイプは、隣接する2ないし複数の空間をまたぎ貫く 線的な際立ち光が、それら空間の連結線となって、架間を連結する光 効果々整理した。

\section{9）分節の強調}

9.1）分節の強調／接空間の境界にある・線的、面的・際立ち光 サンフランシスコ・タッシジ教会（図6）では、祭壇空間と会衆 席空間の境界部分にあたるところにスリット状の線的な光が上部を卜 ンネル状に覆い、その光源およびそこから下に降り注ぐ光が、祭壇と 会衆席の分節老強調している(光形態比 $1: 26$ )。ケネス・フランプト ンはこの教会について光は主に祭壇の直前、上から降り落ちてき、祭 壇之会营席は、この光の結果、分離される。」記述している22。空 間の隣接部分の境界線の全周長に対する光の長さ率は、床面部分を除 きトンネル状の線的な光の為 $65 \%$ であった(隣接長さ率)。入り口付近 から知覚状態を検討してみる之、視野 60 度内で手前の空間之、視野 29 度内で向こうの祭壇空間が同時に知覚出来る。東京カテドラル（写真 15）では、大聖堂からエントランスへの進行方向上で、連続した空間 と天井のスリットから壁面を伝う面的な光が 2 重に舞降りる様が同時 に知覚出来、暗い空間の境界部分で光か際立って、暗・明・暗の対比 を作り出し、天井高の変化と共にその変化点での空間の分節を光か強 調していた。また鉛直方向の例のハキアソフィア（写真 16）では、 40 個の点的な害がドーム基部に連続して配され、それを $55 \mathrm{M}$ 程度の遠 くから眺める為その光は連続した帯のようにみえ、上部のドームを下 部の空間から分節し浮かび上がらせていた。前川道郎はこのドームについ て「大ドームは根元に40の空があけられて、本当に丸い光の帯の上にた

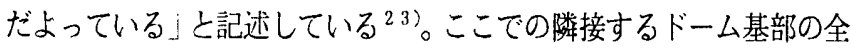
周長に対する光の長さは、約70\%であった。またドーム基部までの視 角度は 45 度で、見やすい視野内で下方の空間之同時に知覚出来る。

隣接する空間のその境界部分を強調することによって、その分節感 は強まると考えられる(図 5ａ） ${ }^{24) 。 ~}$

以上よりこのタイプは，隣接する空間の境界部分にある線的或いは 面的な際立ち光によって、手前の空間、境界部分の光、向こうの空間、 に暗・明・暗の対比を生じさせ、そ㧈空間の分節を強調する光効果 に整理した。

\section{2）分節の強調 /別空間に绦接する・塊的・際立ち光}

京都国立近代美術館（写真 17、図 7) のエントランスホールでは、 異なる天井高さによってろつの空間に分節さ机え㧈らをつなぐ階段が 設けられているが、一番奥の空間は吹き抜け上部の全面トップライト からの光に満ちあふ小机、また大理石水磨きの壁に反射して、塊的な明 るい光の領域として捉元ら机 (光形態比 $1: 2: 3(\mathrm{H})$ )、手前の空間と の明るさの相違によりその分節考強調していた。鉛直断面的に視角度

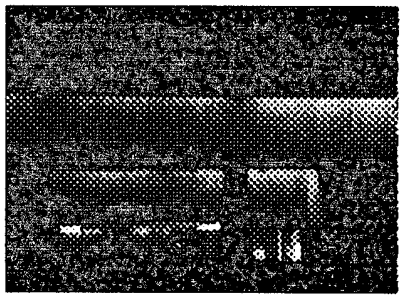

写真 15 : 東京カテドラル

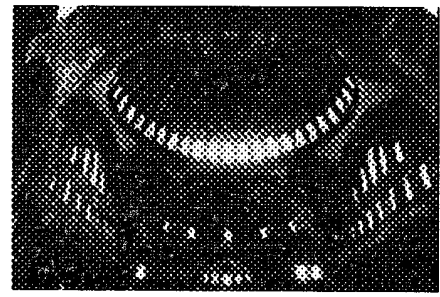

写真 16 : ハキアソフィア

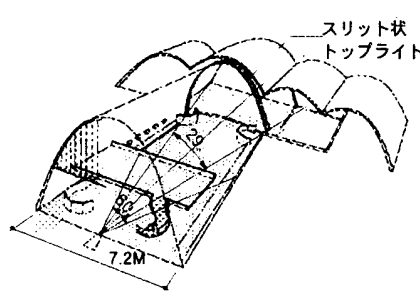

图 6 :サッフラシシスコ・ダทシジ教会

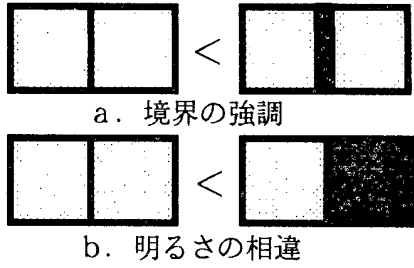

图 $5:$ 領域間の分飾感の強さ

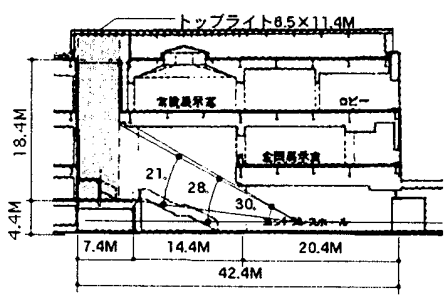

图 7 : 京都国立近代美術館

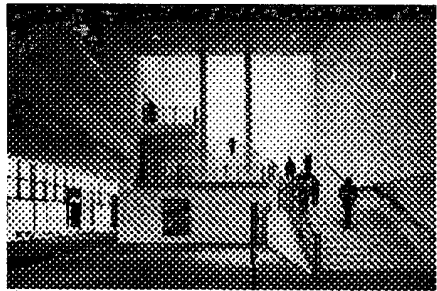

写真 17 : 京都国立近代美術館 
2)物や空間の既往の形態構成理論等と一致した光効果とその要因が多 かったが、際立ち光種類を要因とする光効果まで踏み込んだことに よって、床一面の面的な反映際立ち光による水平基盤面の広がり与え 亡空間への梁み与え、等質際立ち光の空中充満によるまとまり与え、空 間全限定面の面的な等質際立ち光による方向性・距離感の弱めといっ た、物にはない光に特徴的な効果とその要因の構造タイプが得られた （表 2 の 2 縦軸、構造夕イプNo.に○印のもの）。

\section{3 㗚题}

1）代表実例の吟味に際し判断基準しして参考値等を示しながら、幅広 い光効果とその要因を定性的に体系化したが、今後は本成果を基に、要 素を抽象した模型やコンピューターシミュレーション等による評洒実 験より、効果の強弱とその要因の定量的な関係を挆る事によってより 実用性の高い資料に発展すると思う。

2) 効果創出の前提条件として, 光と空間の知覚のしやすさの確認を おこなったが、視野を越えるように光を見せ広がりを強調するなど、知 覚状態の具体内容が効果の必要条件となったり，効果の強弱に関わる 場合がありそうであるが，それらの検討付今後の課題と考える。

3.) 空間の明るさ等も重要な要因となる開放感、広さ感など、本研究 の空間に対する光の構成を主要因とする光効果という視点を越える空 間的効果は扱えていない。

4）約 2000 例の多様な実例の観察より帰納的に、9つの空間秩序的光 効果とその 15 要因構造夕イプという、ある程度幅広い効果とその要 因が得られたと考えるが、その他にも重要な効果と要因があるかどう かにういては吟味出来ていない。今後空間の構成要素や複数空間の組 織化に関する研究なよ゙を体系的にあたって、それらの中に今回の光効 果と要因を位置付けながら演繹的な考察を行なうことによってそれら の吟味できるように思う。

\section{注}

1)こ㧈らは当鈴木砢究室における20 数年にわたる光空間（自然光を主要素とする架間） 研究で扱った実例であり、威力的な太留光をもつ建筑空間を解説した文献、近代建筑や各 理歷史的な建筑の研究書や紹介書、また建築維誌などから、光空間として邆定し、图や写 真、実例代対方方作者や第了者の記述等の資料收集、実地調查等を行ってきたものである。

2)このような判断は本研究の基本設計等の段階で用いやすいレベルて整理するという视 点、及び幅広い効果之要因を扱うさいう点において、一気に細加物理量にまで踏み込ん で捉えるより位、定性的ではあるがこのレベルで、その作り出し素材などとセットで提え ておいた活うか、基本設計等の段階で用いやすいという考えより採用している。

3）視点場について体、架間への入り口の位置、光の位置、空間の使われ方なとを考虑し て妥当之判断したものについては原則として、水平方向八の梘線が支配的と判断した実例 は、その空間の端から光を正面方向に見た場合。鈶直方向八の梘線が支配的と判断した害 例については、空間の中央を視点場とした。尚、梘高さは 1600 之し、明ら加座位之判断 できる場合は 1200 上した。参考:三浦金作「梘党的槽造よりみた広場の尺度 イ例7の広

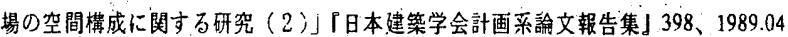

4）見易い梘野域については、芦原義信をはじあ建策や景锶分析に広く用いられることが

多い60度のコーンを採用した。昔原載信『外部空間の設計⿺ (彰国社、1975)。

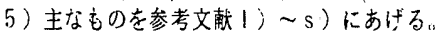

6）茶室・月光院の研究において、見易い視野域６０度内に、左右の壁、天井、床が納ま る為に路時にその全体が把握しやすいという特徽が指摘されている。かたちのテータフフ イル」 o) p.20

7）鈴木信宏「水空間の演出」n) p.29

8)色の現われ方として、表面色、平面色、透明色、鏡映色といった分類かされている。そ こでは、表面色住、色紙やそのほかの不透明物体の表面に通常見られる現われ方で、定位

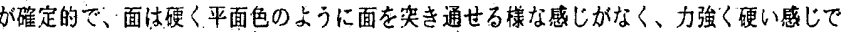

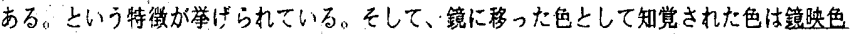
として分類されている。和田陽平「色彩の知賞」q)。

9）鍮木信宏「水架間の演出」n）p.29

10）乾正雄他 「新建筑学体菜 11 瞢境心理」 r) p. 94 。

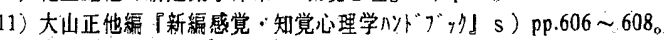

12）乾正雄他『新建築学体系11 㻴境心理」 r) p.93。

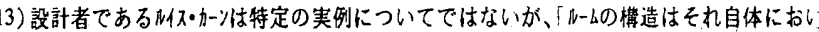

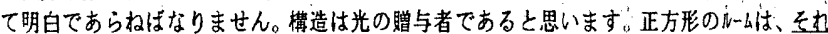
自身の光の中で正方形が譊み取九ることを求めます。つまり空もしくは入り口の光が、上

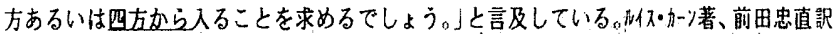

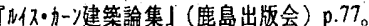

14）D.K.チン「建築のかたちと筀間をデザイすする」1) p.28、pp.51.53

15)この建物はパンタドーム構法で作られているが、リストアップ時のヒンジ・ラインか ら四隅へ向けてトップライトが設けら机、その橦造がそのまま建物の表情となっている。 と言及されている。親建築社户現代建築の潮流」(新建筑社、1995.12) p.487

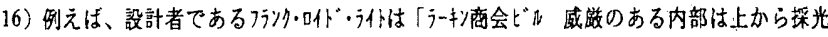

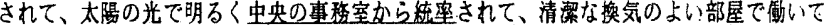

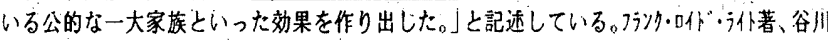

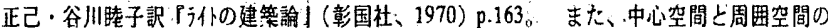

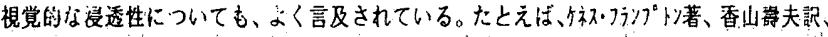
『G A SPECIAL ISSUE 2 」(A.D.A. EDITA TOKYO, 1981) p. 126

17)ここでは小部厔から淔接その中心空間はみえないか、その光はよく知覚できるよう である。設計者である原広司仙「各々の部屋法、内核のトップライ、かから落ちる光を、第 20屋根〉を通して共有する。すちろん各部屋に空があるから日照は得られるが、第 20 屋根からくる光のほうが明るい。」記透している(建築文化」79年 12 月号)。またこの 空間の求心性については以下の記迢がある:「トップライト採光の吹き抜け空間の中に屋内 トップライトを持つ個室を配置した構成。採光を二重にろ過された外光に頼万個室に沐内

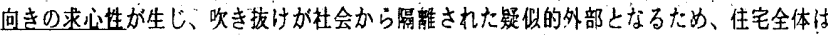
強い開鎖性を带ひている」日本建築学会偏『コンパクト建築設計資料集成（住居偏）』(丸 善、1991) p.42。

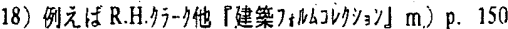

19）列之ば高橋研究室「かたちのデー477似。）p.13

20）鈴木信宏・明田川洋「德利屋」h) p.57。

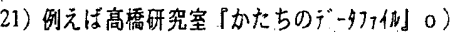

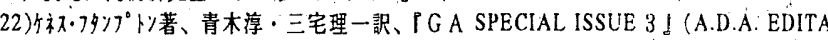
TOKY0, 1983) p.444。

23）前川道郎「ゴシタクということ」(学芸出版社、1992）p.28

24）险接して置かれた空間において、その境界部分の面の区切り方や床の高ざといったる の境界部分の扱い方か、2つの空間を一体化したり、分離させたりとその2 空間の関保を

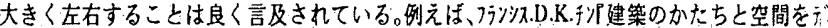
ザインする」 1) p.102。

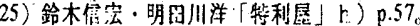

26)「現象的境界は、一般的には異なる煇度また沈波長をもった光によって剌激される視野 の二つの頜域の境界に相当する、刺激における変化が存在する線を境界上して、等啠的斿 領域がそれぞれまとまりをつくり、異質な領域とは、分雖する」と言われている。

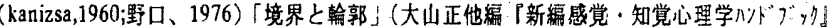
s) p. 604 o

\section{参考文䰚}

a）小泉隆、桶師徳行、鈴木信宏「自然光の構成上その知覚状態加みた建築贺間におい るまとまりと方向性を与える自然光 $917^{\circ}$ 」「日本建筑学会計画系論文集」、第482号, 1996.04 b) 中村芳樹，乾正雄「オフィスの輝度分布特性とその心理効果!同、445号，1993.03

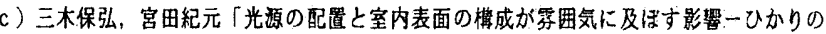
空間的配分に関する研究」.同、488号、1996.10。

d）李善永、石原従道、平手子太郎、安阙正人「住宅居間における明るさの分布が心理評 洒に及ばす影䇺に関する研究」同、497号、1997.07。など

e）中村上、竹内義雄、茶谷正洋、乾正雄「光源の梘覚的効果に関方る研究その1輝きの 領域設定」「日本建築学会大会学術梗概集」1982.10、N N .4022

f）國鴄道子、梁濑慶子「室の好ましい明る゙さと室内霧囲気の評価!同、No:4177、1984:10 など

g) 图嶋道子、梁瀬慶子「生活行為からみた天井照明の評価」同、No.4147、1983.09。なと h) 鈴木信宏、明田川洋「徳利屋い万りの間の空間棈造上光」阳本建築学会計画系諭文集。 第 421 号、1991.03

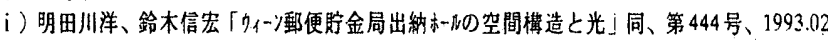

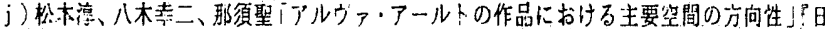
本建穼学会大会梗概集」、N $0.5413 、 19.97 .09$ 。

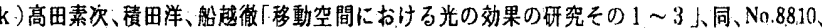
1988.10 と N $0.5367 \sim 5368 、 1997.09$ 。

1)7デシス.D.K.秋、太田邦男訳「建築のかたちと空間をデザ付する】(彰国社、1987)

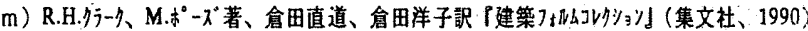

n)鉻木信宏「水空間の演出】(鹿島出版会、1981)

o) 高橋研究室「かたちのテータファイル」(彰国社、1984)

p）本明寛?改訂造形心理学入門』(美術出版社、1962)

q）和田陽平「色彩の知覚」高木貞二、城戸㬝太郎 (編) P実倹心理学概要第 2 巻」(岩波 畫店、1952) pp.59.99

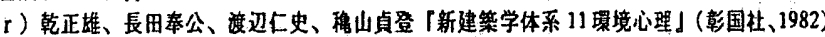
s）大山正、今井省吾、和気典二編「新編感賞・知賞心理学ハンドプック」(誠信㫪房、1994) 